\title{
Isotopic Characteristics of Precipitation and Origin of Moisture Sources in Hemuqiao Catchment, a Small Watershed in the Lower Reach of Yangtze River
}

\author{
Simin $Q u^{1}{ }^{1}$, Xueqiu Chen ${ }^{1}$, Yifan Wang ${ }^{2}$, Peng Shi ${ }^{3, *}$, Shuai Shan ${ }^{4}$, Jianfeng Gou ${ }^{1}$ \\ and Peng Jiang ${ }^{1}$ \\ 1 Department of Hydrology and Water Resources, College of Hydrology and Water Resources, \\ Hohai University, Nanjing 210098, China; wanily@hhu.edu.cn (S.Q.); cxqhhu@163.com (X.C.); \\ jf_gou@sina.com(J.G.); peng.jiang@dri.edu (P.J.) \\ 2 Department of Reservoir Product, Ningbo Hongtai Water Conservancy Information Technology Co., Ltd., \\ Ningbo 315000, China; wyf3584@163.com \\ 3 State Key Laboratory of Hydrology-Water Resources and Hydraulic Engineering, Hohai University, \\ Nanjing 210098, China \\ 4 Department of Modeling, Nanjing Huishui Software Technology Co., Ltd., Nanjing 210019, China; \\ shanshuai@hhu.edu.cn \\ * Correspondence: ship@hhu.edu.cn; Tel.: +86-138-1307-7076
}

Received: 31 July 2018; Accepted: 27 August 2018; Published: 31 August 2018

\begin{abstract}
The stable isotopes of oxygen and hydrogen in the water cycle have become a significant tool to study run-off formation, hydrograph separation, and the origin of precipitation. Precipitation assessment based on isotopic data has a potential implication for moisture sources. In the study, $\delta \mathrm{D}$ and $\delta^{18} \mathrm{O}$ of precipitation samples collected from six rainfall events were analyzed for stable isotope composition to provide implication of isotopic characteristics as well as moisture sources in Hemuqiao basin within Lake Tai drainage basin, eastern China. In these events, stable oxygen and hydrogen isotopic composition of precipitation had strong variations. Models of the meteoric water line and deuterium excess for different rainfall types (typhoon and plum rain, which is caused by precipitation along a persistent stationary front known as the Meiyu front for nearly two months during the late spring and early summer between eastern Russia, China, Taiwan, Korea and Japan) were established. Compared with plum rain, the moisture source of typhoon events had higher relative humidity and temperature. Moisture transport pathways were traced using the Hybrid Single-Particle Lagrangian Integrated Trajectory Model (HYSPLIT Model, developed by NOAA, Washington DC, U.S.) to verify the linkage with isotopic composition and moisture source. The moisture sources of typhoon events mostly derived from tropical ocean air with higher isotopic value, while that of plum rain events came from near-source local air with lower isotopic value.
\end{abstract}

Keywords: isotopes; precipitation; meteoric water line; deuterium excess; moisture source; HYSPLIT model

\section{Introduction}

Oxygen and hydrogen isotopes in hydrological cycle have been utilized for many years. The International Atomic Energy Agency (IAEA) cooperated with the World Meteorological Organization (WMO) accomplishing a worldwide program named Global Network of Isotopes in Precipitation (GNIP) to research the isotopic composition in precipitation since 1958. As a critical role in the exchange process of material and energy between atmosphere and hydrosphere, precipitation plays a significant part in the water cycle [1]. Changes in isotopic composition in precipitation often reflect 
some information of evaporation, relative humidity, condensation or temperature in moisture transport source [2,3]. Hence, this study will improve the knowledge of isotopic composition in precipitation and its moisture source in a typical basin, eastern China.

Many studies have been conducted on spatial and temporal variation in precipitation using stable isotope concentrations $\left(\delta^{2} \mathrm{H}\right.$ and $\left.\delta^{18} \mathrm{O}\right)$ [4-6]. These can be applied to show the information of run-off formation, moisture source, and paleoclimate interpretation $[7,8]$. Previous studies have indicated that the main factors affecting the stable isotope in precipitation include moisture source, temperature, continental effect, and amount [9-13]. In some subtropical basins, studies were conducted to demonstrate negative correlations between $\delta^{18} \mathrm{O}$ and precipitation as well as $\delta^{18} \mathrm{O}$ and temperature in south western China [14] and Urumqi river basin [15]. Furthermore, $\delta^{18} \mathrm{O}$ values of precipitation with temperature and latitude partly reflected geographical influences and long-term temperature changes [16].

The meteoric water line and deuterium excess can serve as two indicators to measure the characteristic of stable isotopes in precipitation. Some isotopic atmosphere models examined the capacity of the meteoric water line to give equal weighting regardless of the precipitation amounts [17-19]. The use of deuterium excess to identify the origin of ice bodies during equilibrium freezing confirmed the secondary processes in ice core studies [20-22]. Thus, the studies of deuterium excess suggested that it is highly sensitive to processes that generate the kinetic fractionation effect. Deuterium excess has been shown to indicate the moisture sources and sub-cloud processes for rainfall events $[23,24]$. In reality, a smaller precipitation amount tends to have a lower deuterium value due to re-evaporation in raindrops. A larger precipitation amount presents a heavier isotope with fairly lower condensation temperature and limited exchange in water vapor below the cloud [25]. As a new instrument, deuterium excess (d-excess) can also enhance spatial monitoring when tracking the magnitude footprint of regional water cycling [26].

$\delta^{18} \mathrm{O}$ signatures of stable isotopes in precipitation can provide information of its moisture source and transport pathways. Isotopic samples collected from stations in southern China demonstrated that spatial distribution of $\delta^{18} \mathrm{O}$ could portray the moisture sources [27]. A survey of central Asia reported that the moisture sources on the northern slope of the Himalayas and southeastern Tibet were derived from Indian and Pacific Oceans [28]. Similarly, under the influence of a monsoon, a distinct seasonality of d-excess suggested the summer monsoon is the moisture source of Tibetan Plateau [29]. Monsoon systems affect the precipitation of monsoon regions by affecting the distribution of air mass transportation and balance of water vapor. Hence, moisture sources make it possible to control spatial and temporal variation of precipitation [12]. High isotopic concentrations of precipitation are associated with rainfall events sourced from remote westerly air masses.

In recent years, a trajectories analysis method based on the Lagrangian method has offered important support for water source transport process and source-sink study. By defining three-dimension mobile trajectories of calculated air parcels, the Lagrangian method can determine the transport source locations of air parcels. Some researchers reported a water source study in detail using the HYSPLIT model for extreme rainfall events [30], high altitude snow areas [31], continental, and island sites [23]. Plum rain, precipitation along a persistent stationary front known as the Meiyu front for nearly two months during the late spring and early summer between eastern Russia, China, Taiwan, Korea and Japan, and typhoons are two different kinds of climate systems; thus, it is of significant importance to understand the mechanism of two rainfall types using isotopic characteristics and the HYSPLIT model.

Several researchers linked the isotopic composition of water sources using the HYSPLIT model, especially comparing typhoon events and plum rain. To study the isotopic characteristics of precipitation and moisture sources in Hemuqiao catchment, we collected samples for selected rainfall events and investigated the temporal variation of isotopic composition and transport pathways using the HYPLIST model. The stable isotope information obtained from precipitation could 
provide a meaningful implication for future hydrograph separation and modeling studies for Hemuqiao catchment.

\section{Materials and Methods}

\subsection{Study Area}

This study was conducted in Hemuqiao small catchment in the lower reach of Yangtze River, at latitude $119^{\circ} 47^{\prime} 05^{\prime \prime} \mathrm{E}$ to $119^{\circ} 48^{\prime} 20^{\prime \prime} \mathrm{E}$, longitude $30^{\circ} 34^{\prime} 05^{\prime \prime} \mathrm{N}$ to $30^{\circ} 34^{\prime} 55^{\prime \prime} \mathrm{N}$. Hemuqiao catchment is located in the middle of the plain between the Hangzhou Bay and Lake Tai in Yangtze Delta plain, with a basin area of $135 \mathrm{ha}$ and elevation ranging from $150 \mathrm{~m}$ to $600 \mathrm{~m}$ (Figure 1). The catchment has a typical subtropical monsoon climate with abundant sunlight and rainfall in summer. The annual average temperature is $14.0^{\circ} \mathrm{C}$ with an annual rainfall of $1580 \mathrm{~mm}$ and annual evaporation from the water surface of $805 \mathrm{~mm}$. Rainfall is mainly concentrated in three months, June, July and August. The geographic type of the basin has multilayers, resulting in variability of soil types. Based on the mountainous and hill area, the vegetation level of basin has mainly bamboo without sewage discharge. The river has two tributaries to the outlet and it has discharge most of the year. In the basin, Hemuqiao hydrological station and a meteorological station were constructed.

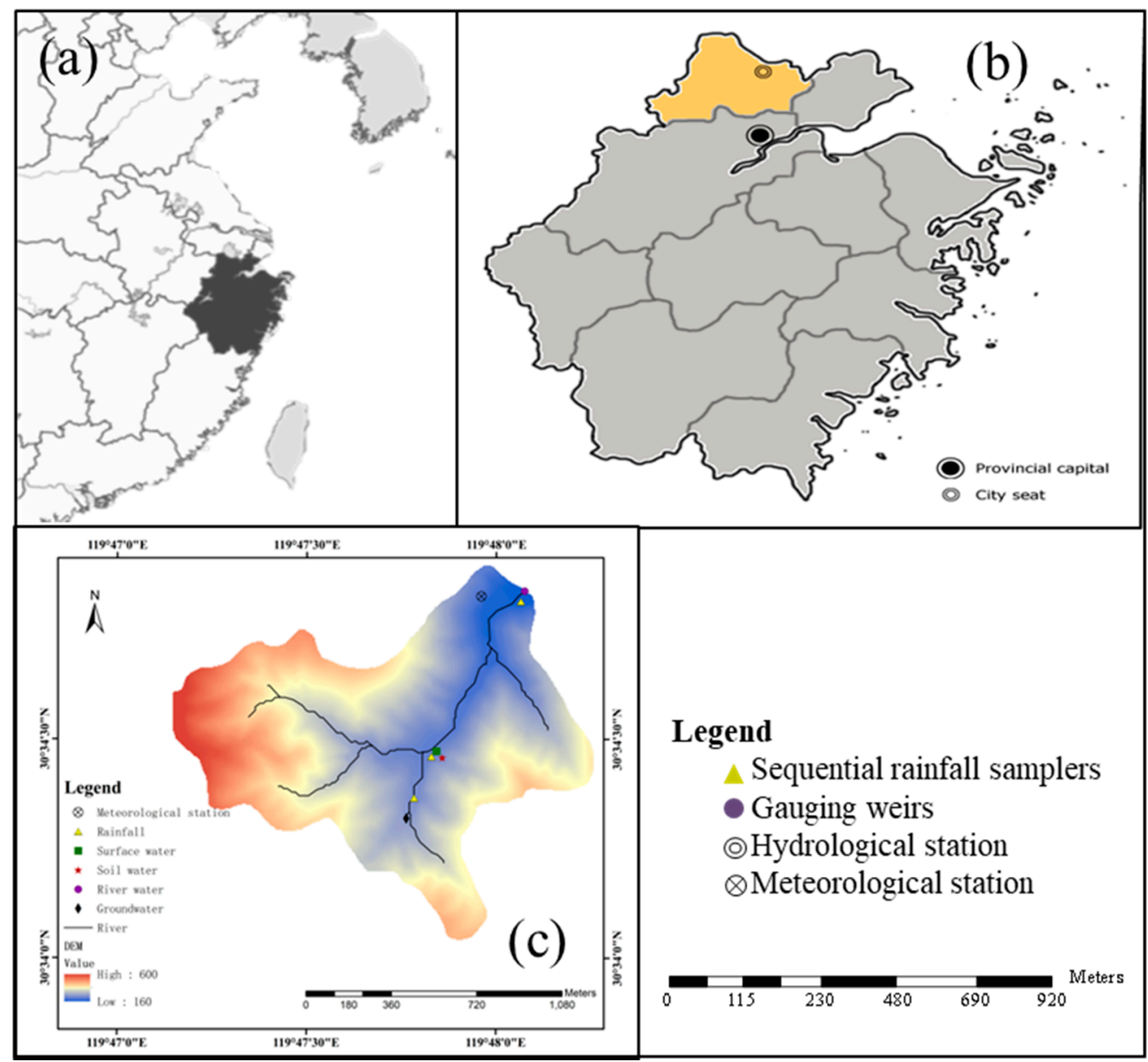

Figure 1. Locations of Hemuqiao catchment and distribution of sampling sites. (a) The location of Zhejiang Province in China. (b) The location of Huzhou City in Zhejiang Province. (c) Locations of sequential rainfall samplers, hydrological station and meteorological station in Hemuqiao catchment. 


\subsection{Instrumentation and Event Sampling}

Precipitation samples were collected for four typhoon events and two plum rain events that occurred from August in 2015 to October in 2016. Sequential rainfall was measured in this study using a kind of sequential rainfall sampler modified from Kennedy [32]. In the sequential sampler, water was collected in eight polyethylene bottles from the upper 5.5-cm-radius funnel that flowed into the lower sample bottles in sequence. Every bottle had a guide rod to ensure the balance of pressure between the inner bottle and barometric pressure. When all the bottles were filled, the rest of the water flowed out of these samples into a storage tank at the bottom. The bottle size for rainfall was $250 \mathrm{~mL}$, representing a $2.63 \mathrm{~mm}$ rainfall amount. Stream water was collected in the outlet of the basin before the events, in the events and after the events, until the discharge receded.

All the collected samples were preserved in $30 \mathrm{~mL}$ sample bottles with a waterproof bond sealed at 4 degrees. Oxygen and deuterium were analyzed by mass spectrometry (MAT523) in the State Key Laboratory of Hydrology-Water Resources and Hydraulic Engineering at Hohai University. The samples of deuterium were obtained by the $\mathrm{H}_{2}-\mathrm{H}_{2} \mathrm{O}$ equilibrium method with a platinum catalyst, and the samples of oxygen were obtained by the $\mathrm{CO}_{2}-\mathrm{H}_{2} \mathrm{O}$ equilibrium method [33]. Isotopic concentration was expressed as parts per million with respect to Vienna Standard Mean Ocean Water (V-SMOW) [34], based on this equation:

$$
\delta^{18} \mathrm{O}=\left(\mathrm{R}_{\text {sample }} / \mathrm{R}_{\text {SMOW }}-1\right) \times 1000
$$

where $\mathrm{R}_{\text {sample }}$ is the ratio of ${ }^{18} \mathrm{O} /{ }^{16} \mathrm{O}$ of samples; $\mathrm{R}_{\text {SMOW }}$ is the ratio of ${ }^{18} \mathrm{O} /{ }^{16} \mathrm{O}$ of SMOW; $\delta$ is the isotopic concentration in \%o. The respective test precision of ${ }^{2} \mathrm{H}$ and ${ }^{18} \mathrm{O}$ is $\pm 0.2 \%$ and $\pm 1 \%$.

Meteorological data were calculated based on global reanalysis data of NCEP (National Centers for Environmental Prediction), which can be downloaded from the NOAA website (https:/ /www. ncdc.noaa.gov /data-access/model-data/model-datasets/reanalysis-1-reanalysis-2).

\subsection{HYSPLIT Model}

The HYSPLIT (the Hybrid-Single Particle Lagrangian Integrated Trajectory) model was developed by the National Oceanic and Atmospheric Administration (NOAA) Air Resource Laboratory (ARL) [35-37]. This model is a complete system for computing simple air parcel trajectories, as well as complex transport, dispersion, chemical transformation, and deposition simulations. Each back trajectory analysis was applied to determine the origin of air masses and establish source-receptor relationships. The model is a kind of dispersal pattern of the Eulerian-Lagrangian mixed approach, whose advection and diffusion calculation uses the Lagrangian method. Its topography $\sigma$ coordinate keeps the original meteorological data format on horizontal coordinates and interpolates the topography $\sigma$ coordinate system based on vertical coordinates:

$$
\sigma=\left(\mathrm{Z}_{\mathrm{top}}-\mathrm{Z}_{\mathrm{mst}}\right) /\left(\mathrm{Z}_{\mathrm{top}}-\mathrm{Z}_{\mathrm{gl}}\right)
$$

where $Z_{\text {top }}$ is the top of the coordinate system of the trajectory model; $Z_{\mathrm{gl}}$ is the elevation of topography; $Z_{\mathrm{mst}}$ is the lower boundary elevation of coordinates.

When particle movement trajectories carried by air were calculated, the final position was derived from the mean velocity calculation of the original position $(\mathrm{Q})$ and the first-guess position:

$$
\begin{gathered}
\mathrm{Q}^{\prime}(\mathrm{t}+\Delta \mathrm{t})=\mathrm{Q}(\mathrm{t})+\mathrm{V}(\mathrm{Q}, \mathrm{t}) \Delta \mathrm{t} \\
\mathrm{Q}(\mathrm{t}+\Delta \mathrm{t})=\mathrm{Q}(\mathrm{t})+0.5 \times\left[\mathrm{V}(\mathrm{Q}, \mathrm{t})+\mathrm{V}\left(\mathrm{Q}^{\prime}, \mathrm{t}+\Delta \mathrm{t}\right)\right] \Delta \mathrm{t}
\end{gathered}
$$

where $\Delta \mathrm{t}$ is the backoff time step, for example, $\Delta \mathrm{t}$ in this study is $72 \mathrm{~h}$. 


\section{Results}

\subsection{Isotopic Characteristics of Atmospheric Precipitation}

The stable isotopic composition of precipitation has a significant difference when bound up with the water state. In particular, equilibrium fractionation and kinetic fractionation exist in isotopes, i.e., there is a difference in precipitation at different times. In order to study the isotopic values of precipitation, we observed hydrological data both in typhoon events and plum rain events, considering the comparison of different rainfall types.

Previous studies indicated that the distribution of the stable isotope of precipitation can be impacted by precipitation mechanism, geography condition, moisture sources and rainfall duration $[14,38,39]$. To qualify the influence of isotopic characteristics in precipitation, $\delta^{18} \mathrm{O}$ and $\delta^{2} \mathrm{H}$ values were measured during the four typhoon events and two plum rain events (Table 1).

Table 1. $\delta^{18} \mathrm{O}$ values in precipitation for six selected rainfall events (the column "date" 20150809 indicates the flood starting time on the 9 August 2015).

\begin{tabular}{ccccccccc}
\hline $\begin{array}{c}\text { Event } \\
\text { Number }\end{array}$ & $\begin{array}{c}\text { Rainfall } \\
\text { Types }\end{array}$ & Date & $\begin{array}{c}\text { Rainfall } \\
\text { Amount/ } \\
\mathbf{m m}\end{array}$ & $\begin{array}{c}\text { Sample } \\
\text { Numbers }\end{array}$ & $\begin{array}{c}\text { Average/ } \\
\text { \%o }\end{array}$ & $\begin{array}{c}\text { Maximum/ } \\
\text { \%o }\end{array}$ & $\begin{array}{c}\text { Minimum/ } \\
\text { \%o }\end{array}$ & $\begin{array}{c}\text { Standard } \\
\text { Deviation }\end{array}$ \\
\hline 1 & $\begin{array}{c}\text { Soudelor } \\
\text { Typhoon }\end{array}$ & 20150809 & 99.2 & 26 & -4.78 & -3.56 & -6.82 & 0.76 \\
\hline 2 & $\begin{array}{c}\text { Hato } \\
\text { Typhoon }\end{array}$ & 20150823 & 47.4 & 40 & -9.31 & -7.48 & -10.66 & 1.10 \\
\hline 3 & $\begin{array}{c}\text { Dujuan } \\
\text { Typhoon }\end{array}$ & 20150930 & 13.2 & 21 & -6.94 & -4.65 & -9.64 & 1.68 \\
\hline 4 & $\begin{array}{c}\text { Meranti } \\
\text { Typhoon }\end{array}$ & 20160915 & 88.8 & 17 & -10.87 & -8.25 & -13.52 & 1.13 \\
\hline 5 & $\begin{array}{c}\text { Plum } \\
\text { rain }\end{array}$ & 20160624 & 62 & 50 & -8.13 & -5.81 & -10.38 & 1.29 \\
\hline 6 & $\begin{array}{c}\text { Plum } \\
\text { rain }\end{array}$ & 20160710 & 145.6 & 16 & -7.23 & -5.39 & -9.14 & 1.42 \\
\hline
\end{tabular}

Temporal variations of $\delta^{18} \mathrm{O}$ and $\delta^{2} \mathrm{H}$ values in rainfall were analyzed during six rainfall events in Hemuqiao catchment (Figure 2). There were strong temporal variations of the six rainfall events along with significant variation of $\delta^{18} \mathrm{O}$ and $\delta^{2} \mathrm{H}$ values. On the whole, $\delta^{18} \mathrm{O}$ and $\delta^{2} \mathrm{H}$ values had a similar change tendency as the sample numbers increased. With the increasing sample number, isotopic data of four rainfall events could be clearly seen as an enrichment trend (Event 1, 3, 5 and 6), which contains the two plum rainfall events and two typhoon events, reflecting mainly condensation of ${ }^{18} \mathrm{O}$ and ${ }^{2} \mathrm{H}$ in precipitation down to the ground. The isotopic temporal variation in Event 2 and 4 had a fluctuating trend with a peak and trough. Hence, precipitation was enriched in the heavy isotope at the beginning of rainfall and depleted after the rainfall period. As for the two typhoon events, the isotopic value of precipitation appeared not to have stable variation trend but a remarkable change, which might be affected by features of typhoon events and meteorological elements.

In order to justify the variation of isotopic temporal series in rainfall, the average, minimum, maximum and standard deviation of $\delta^{18} \mathrm{O}$ and $\delta^{2} \mathrm{H}$ are shown in Tables 1 and 2. In general, for all the rainfall events, the $\delta^{18} \mathrm{O}$ value varied from $-13.52 \%$ to $-3.56 \%$ with an average of $-8.29 \%$; while $\delta^{2} \mathrm{H}$ varied from $-95.28 \%$ to $-17.98 \%$ o with an average of $-47.90 \%$. This showed that different rainfall types had different variations. As different rainfall types have disparate moisture sources and precipitation mechanisms, the isotopic characteristics have great changes. The smallest and largest $\delta^{18} \mathrm{O}$ and $\delta^{2} \mathrm{H}$ values during rainfall both occurred in typhoon events (Event 3 and Event 4 ). This result indicated that precipitation isotope compositions in typhoon events presented larger variations than those in plum rain events. Average isotopic values of plum rain were lower than in typhoon events 
except Event 4, which is significant to state the distinction between typhoon and plum rain, which is mainly caused by formation of plum rain with a mixture of deep convective clouds and stratiform clouds. The average $\delta^{18} \mathrm{O}$ value of typhoon events is higher than that of plum rainfall events in 2016. Event 4 had the most negative $\delta^{18} \mathrm{O}$ value and second most negative $\delta^{2} \mathrm{H}$ value different from other typhoon events. This abnormal phenomenon can be explained by water sources analysis.
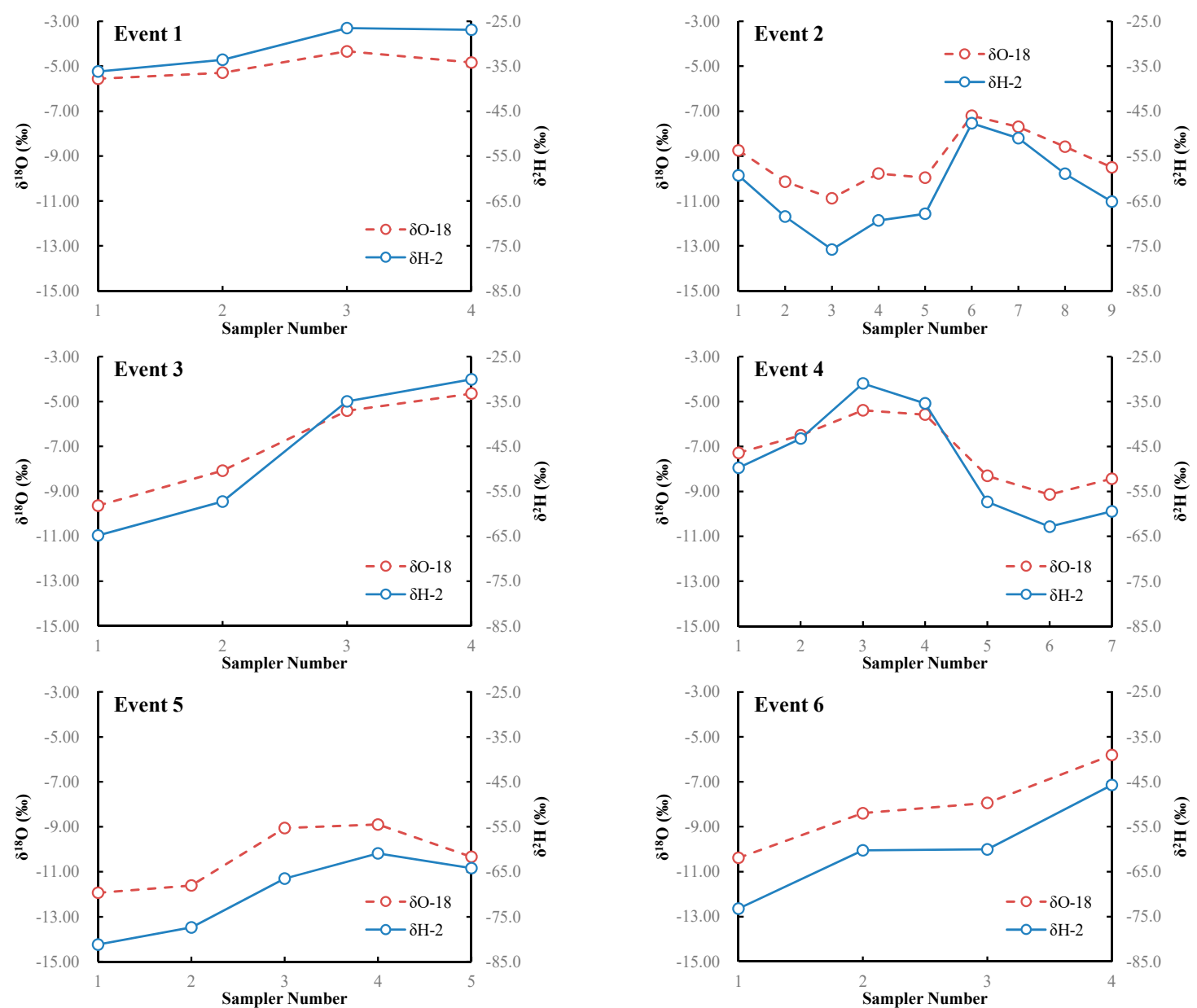

Figure 2. Temporal variation of $\delta^{2} \mathrm{H}$ and $\delta^{18} \mathrm{O}$ in precipitation for six rainfall events. The horizontal ordinate refers to sampler number of sequential rainfall sampler improved from Kennedy. Six figures represent six rainfall events from Event 1 to Event 6, respectively.

Table 2. $\delta^{2} \mathrm{H}$ values in precipitation for six selected rainfall events.

\begin{tabular}{cccccccc}
\hline $\begin{array}{c}\text { Event } \\
\text { Number }\end{array}$ & $\begin{array}{c}\text { Rainfall } \\
\text { Types }\end{array}$ & Date & $\begin{array}{c}\text { Sample } \\
\text { Numbers }\end{array}$ & Average/\%o & Maximum/\%o & Minimum/\%o & $\begin{array}{c}\text { Standard } \\
\text { Deviation }\end{array}$ \\
\hline 1 & $\begin{array}{c}\text { Soudelor } \\
\text { Typhoon }\end{array}$ & 20150809 & 26 & -30.02 & -21.85 & -46.12 & 5.74 \\
\hline 2 & $\begin{array}{c}\text { Hato } \\
\text { Typhoon }\end{array}$ & 20150823 & 40 & -58.26 & -41.72 & -75.80 & 9.36 \\
\hline 3 & $\begin{array}{c}\text { Dujuan } \\
\text { Typhoon }\end{array}$ & 20150930 & 21 & -38.06 & -17.98 & -64.80 & 13.08 \\
\hline 4 & $\begin{array}{c}\text { Meranti } \\
\text { Typhoon }\end{array}$ & 20160915 & 17 & -64.65 & -45.71 & -77.21 & 10.29 \\
\hline 5 & Plum rain & 20160624 & 50 & -54.77 & -30.94 & -64.31 & 9.67 \\
\hline 6 & Plum rain & 20160710 & 16 & -74.24 & -57.61 & -95.28 & 8.76 \\
\hline
\end{tabular}


To a great extent, there is a close relationship between $\delta$ values and rainfall amount. Dansgaard [9] first observed the remarkable relationship between rainfall amount and isotopic composition named this phenomenon the "rainfall amount effect". The effect of amount has been proposed elsewhere in many regions, so we focused on the linkage between the amount effect and isotope data. We analyzed the relationship between rainfall amount in the rainfall concentrated period and precipitation isotope in four rainfall events (Event 3, 4, 5 and 6). The results showed that the dataset had a significant rainfall amount effect, i.e., a negative correlation with a correlation coefficient higher than 0.45 (Figure 3). However, this effect is not remarkable when the amount is small, possibly influenced by isotopic fractionation. A study has shown that the rainfall amount was a pivotal factor controlling the final isotopic value in precipitation at mid-latitudes [13]. The highest ${ }^{18} \mathrm{O}$ values corresponded to the largest rainfall amount in plum rain, but the converse is not generally true (Table 1). A small rainfall event tended to be present a lower $\delta$ value such as for typhoon events.
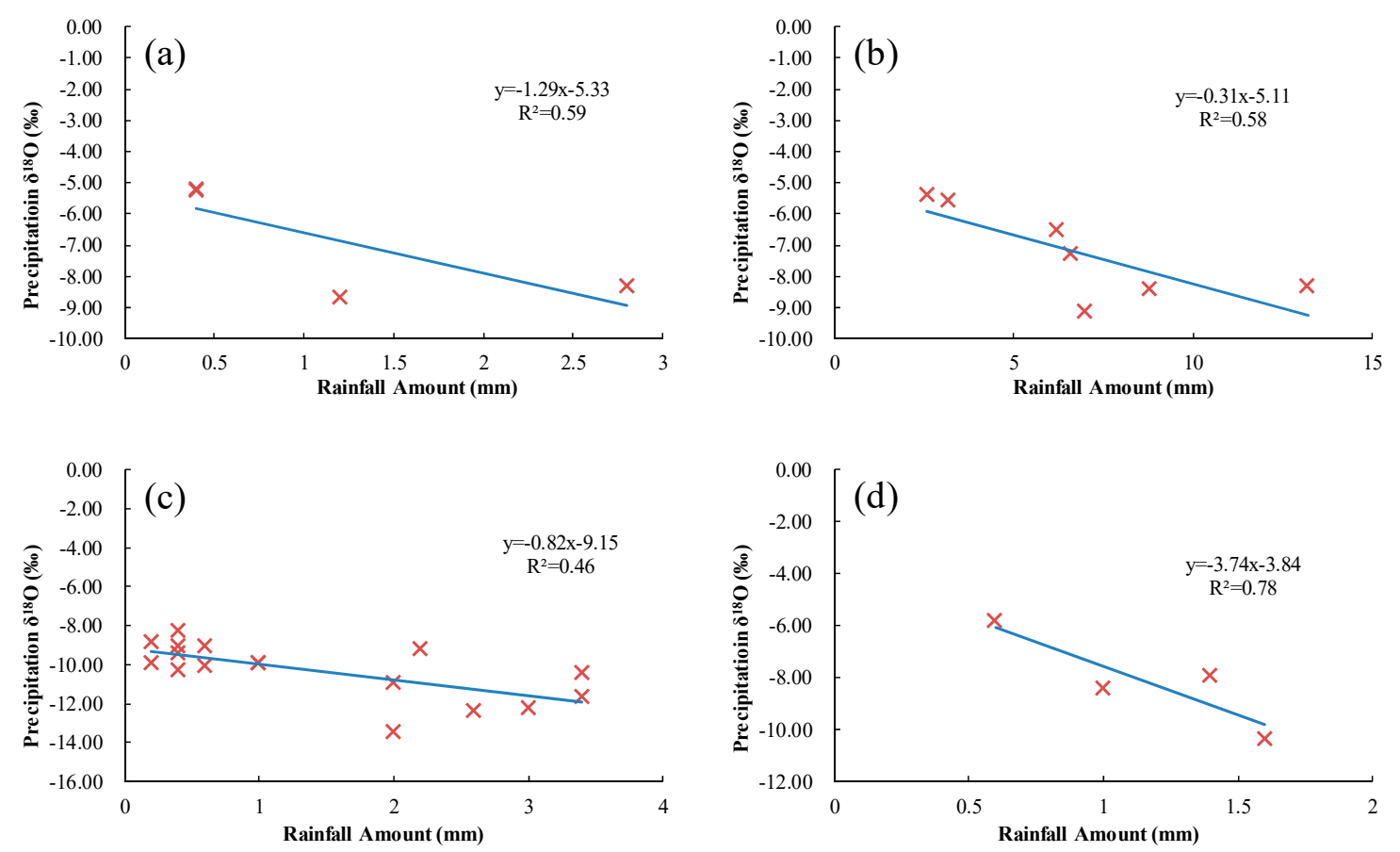

Figure 3. The relationship between rainfall amount and precipitation $\delta^{18} \mathrm{O}$. Figure (a-d) represents event 3, 4, 5 and 6, respectively (represents rainfall amount in one hour and its isotopic value).

\subsection{Meteoric Water Line and Deuterium Excess}

The isotopic composition of atmospheric precipitation changes during the conversion of different phase states of water. Due to temperature and moisture, isotopes in precipitation undergo fractionation in various circumstances, leading to differences in precipitation isotopes among regions. According to analysis of precipitation isotopes in North American, a linear correlation of oxygen and hydrogen isotopic composition in precipitation was concluded, and the GMWL (Global Meteoric Water Line) is: $\delta^{2} \mathrm{H}=8 \delta^{18} \mathrm{O}+10$ [40], and more recent equation with long-term means weighted by the amount of precipitation from the GNIP dataset gave quite similar results: $\delta^{2} \mathrm{H}=8.14( \pm 0.02) \times \delta^{18} \mathrm{O}+10.9( \pm 0.2)$, $\mathrm{R}=0.98$ [41]. But the meteoric water line has an intimate association with latitude, altitude, distance from the coast and the amount of precipitation [41]. From the above research, we found great isotopic changes between typhoon events and plum rain events. By virtue of the meteoric water line and deuterium excess, we justified this source of change based on the isotopic value.

Based on isotopic data of rainfall samples in Hemuqiao basin, the meteoric water line for six rainfall events was calculated by fitting of the least square method: 
$\delta^{2} \mathrm{H}=7.11( \pm 0.09) \times \delta^{18} \mathrm{O}+3.36( \pm 0.79)\left(\mathrm{n}=170, \mathrm{R}^{2}=0.97\right)$, where $\mathrm{n}$ is sample number and $\mathrm{R}^{2}$ is the correlation coefficient. Compared with GMWL, the water line had a lower slope and intercept, mainly because of the occurrence of kinetic fractionation effect after re-evaporation during rainfall. Furthermore, isotopic fractionation occurred easily in transport and rainfall owing to higher temperature and moisture in summer. If the slope and intercept are lower, the rain drops are exposed to intense evaporation. A study on the meteoric water line indicated that evaporation caused secondary raindrops enriched in heavy isotope [42]. Because of little difference with GMWL, ocean air is the main source for the study catchment in flood season.

The typhoon events and plum rain were discussed separately to analyze the reason for differences in the slope and intercept of the meteoric water line for different rainfall types. The two types of meteoric water lines are shown in Figure 3, and the slopes, intercepts and correlation coefficients of regression equations were calculated. The relationship between $\delta^{2} \mathrm{H}$ and $\delta^{18} \mathrm{O}$ had a good linear correlation, considering major axis regression produced large slopes [43]. The MWL of typhoon events was $\delta^{2} \mathrm{H}=7.52( \pm 0.13) \times \delta^{18} \mathrm{O}+6.26( \pm 0.91)$; while that of plum rain events was $\delta^{2} \mathrm{H}=6.17( \pm 0.23) \times \delta^{18} \mathrm{O}-6.42( \pm 2.46)$. The two lines were different in slope and intercept, and they had a lower value, demonstrating that Hemuqiao catchment was influenced by Pacific East Asia monsoon and maritime air is the most major source of precipitation. For air derived from different regions, different stable isotope ratios were all less than 8 , and the results of Hemuqiao catchment also met the following conditions: (1) the evaporation is a non-equilibrium process; (2) the condensation of air satisfied the Rayleigh fractionation produced under equilibrium condition, shifting from a cloud system swiftly after condensation [44]. The intersection of GMWL and LMWL (Local Meteoric Water Line) can reflect approximately the original average oxygen and hydrogen stable isotope composition of the air source. Additionally, the two lines were different from other studies in the same study area [45]. This might result from the selection of different rainfall events.

The condensation in an unsaturated atmosphere is influenced by non-equilibrium evaporation, resulting in a fast velocity of heavy isotope enrichment. Basically, proportional to evaporation velocity and temperature, condensation finally deviated from the condensation line along the direction of increasing stable isotope ratio. This process explained that high temperature and lower humidity generated a smaller slope of the meteoric water line [9]. As we could see from Figure 3, the slope of the meteoric water line in typhoon events is larger than that in plum rain events, on behalf of different meteorological environments for the two types of rainfall. In addition, the meteoric water line of plum rain deviated from GMWL, which indicated that continental air mass contained moisture and only a few air masses originated from the ocean. The meteoric water line of typhoon events was close to GMWL, demonstrating that the most part of the air mass in typhoons came from ocean air mass.

Deuterium excess (d-excess) provides a measure of non-equilibrium isotopic effects because it records the difference between $\delta^{2} \mathrm{H}$ and $\delta^{18} \mathrm{O}$, which is defined as $\mathrm{d}: \mathrm{d}=\delta^{2} \mathrm{H}-8 \delta^{18} \mathrm{O}[9]$. The whole concept of the deuterium excess value depends greatly on the difference in the fractionation velocity of ${ }^{2} \mathrm{H}$ and ${ }^{18} \mathrm{O}$, reflecting the non-equilibrium degree in the process of evaporation and condensation. On the one hand, deuterium excess is affected by climate conditions of the moisture source (temperature, relative humidity and wind velocity). Several researchers showed that d-excess probably increases with elevation in the troposphere [46]. On the other hand, deuterium excess has a relationship with the isotopic fractionation imbalance degree. Previous studies indicated that moisture source relative humidity is the main driver of deuterium excess on seasonal timescales, and deuterium excess also could reflect moisture recycling $[47,48]$. Under the global average condition, $d=10 \% 0$ reflects the meteorological situation of the source region: subtropical and trade wind belts were the evaporation source region of air masses.

Deuterium excess variations were analyzed for selected typhoon events and plum rain event as Figure 4 presented. In Hemuqiao catchment, deuterium excess showed a strong variation during water sample collection. The deuterium excess of typhoon events ranges from $4.06 \%$ to $17.98 \%$ and of plum rain events ranges from $3.45 \%$ to $19.12 \%$. If condensation occurs under the equilibrium condition, 
deuterium excess is $0 \%$ when $\delta^{2} \mathrm{H}$ is $-14 \%$ and $\delta^{18} \mathrm{O}$ is $-3 \%$. After long distance air transport, the stable isotope of precipitation arriving inland is much lower than the above values. The results accorded with this conclusion.
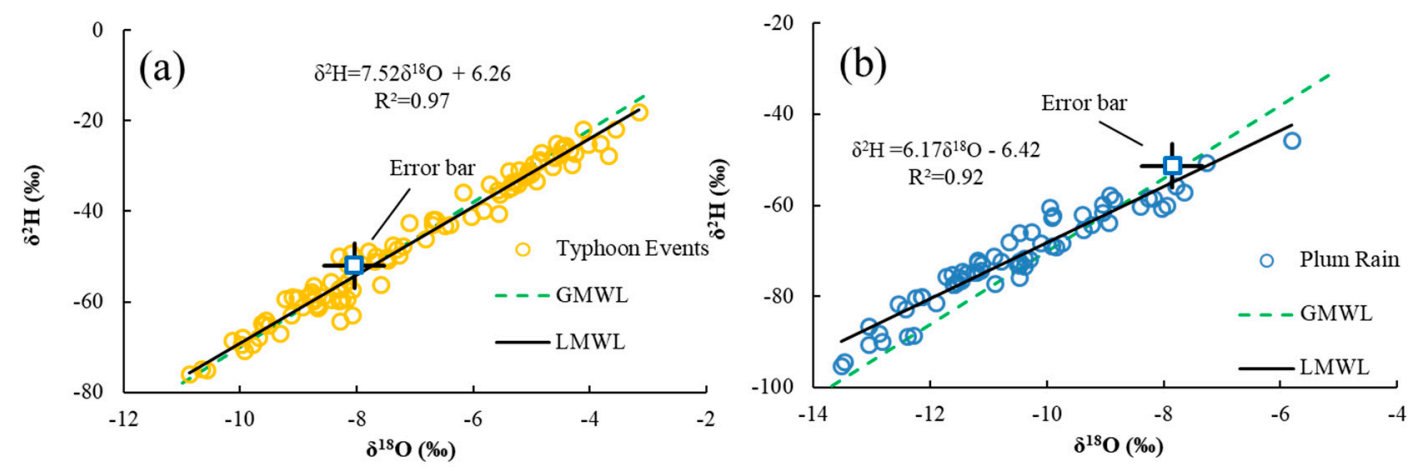

Figure 4. The relationship between $\delta^{2} \mathrm{H}$ and $\delta^{18} \mathrm{O}$ for different types of rainfall (square means the isotopic value of Nanjing station precipitation with error bars). The meteoric water line of typhoon events is in figure (a) with a regression equation: $\delta^{2} \mathrm{H}=7.52( \pm 0.13) \times \delta^{18} \mathrm{O}+6.26( \pm 0.91)(\mathrm{n}=104$, $\left.\mathrm{R}^{2}=0.97\right)$; the meteoric water line of plum rainfall event is in figure (b) with a regression equation: $\delta^{2} \mathrm{H}=6.17( \pm 0.23) \times \delta^{18} \mathrm{O}-6.42( \pm 2.46)\left(\mathrm{n}=66, \mathrm{R}^{2}=0.94\right)$. The dashed lines of the two figures are the global meteoric water line to compare with the relationship between $\delta^{2} \mathrm{H}$ and $\delta^{18} \mathrm{O}$.

Deuterium excess variations are $10.04 \% 0,8.85 \% 0,9.46 \%, 11.43 \% 0,7.20 \%$ and $7.73 \%$. In Event 5 , the $\mathrm{d}$ value is high with lower $\delta^{2} \mathrm{H}$ and $\delta^{18} \mathrm{O}$ values, possibly caused by re-evaporation. Higher deuterium excess and lower isotope reflected dry conditions in continental local water air and their source of water vapor. Event 6 had lower deuterium excess with characteristic convective weather in plum rain, influenced by water evaporation in summer. Events 1, 3, 4 were three typhoon events with lower deuterium excess and higher $\delta^{2} \mathrm{H}$ and $\delta^{18} \mathrm{O}$ values, different from Event 2 . Deuterium excess in Event 2 was large because of the influence of re-evaporation and mixing of different sources, which need further research in water source trajectories. Deuterium excess variation of several events had deficiency in proof of water sources; thus, we could determine moisture transport pathways using the HYSPLIT model.

\subsection{Moisture Source Trajectories}

Precipitation in the flood season in Hemuqiao basin is mainly dominated by typhoon events resulting from tropical air masses in the Indian Ocean and Pacific Ocean. It is known that plum rain is an annual metrological cycle of precipitation in the East Asia monsoon region similar to Baiu in Japan and Changma in Korea. Plum rain occurs from a narrow band with a stationary front between warm and cold air masses during May to July [49,50]. According to cluster analysis of backward trajectories, the information of moisture sources revealed that most trajectories came from warm and humid low latitude areas.

The analysis results of water resource trajectories are shown in Figures 5 and 6. For four typhoon events, Event 1 and 3 had similar moisture transport pathways derived from the eastern India Ocean and Pacific Ocean. In theory, the humid air from Pacific Ocean should have had a lower contribution for isotopic composition in precipitation. However, measured $\delta^{18} \mathrm{O}$ varied from $-9.64 \%$ to $-3.56 \%$ with average of $-4.77 \%$, implying that moisture percentage enriched with a higher isotopic value made a greater contribution than that enriched with a lower isotopic value. Under the influence of three different trajectories, $\delta^{18} \mathrm{O}$ values during this period were negative, suggesting the isotopic value of maritime air mass was depleted in transport from the ocean to the continent. For Event 2, the trajectories were from the East China Sea, apparently different from the other typhoon event. This difference in water source may be the reason contributing to higher 
deuterium excess. For Event 4, the three trajectories were from Pacific Ocean and the East China Sea, which could explain that this event had more negative $\delta^{18} \mathrm{O}$ and $\delta^{2} \mathrm{H}$ values. Previous investigators found the isotopic composition in precipitation of water vapor from near-source local evaporation had lower $\delta$ values [51], which could result in the interpretation of higher average for this typhoon event with larger proportion of near-source air $(72 \%)$.

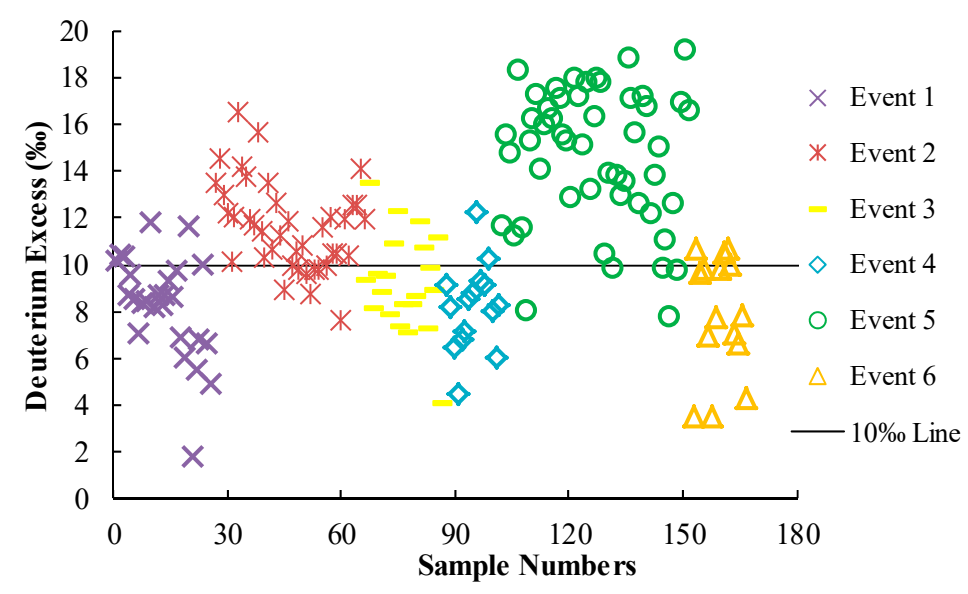

Figure 5. Distribution of deuterium excess in Hemuqiao basin for six rainfall events.

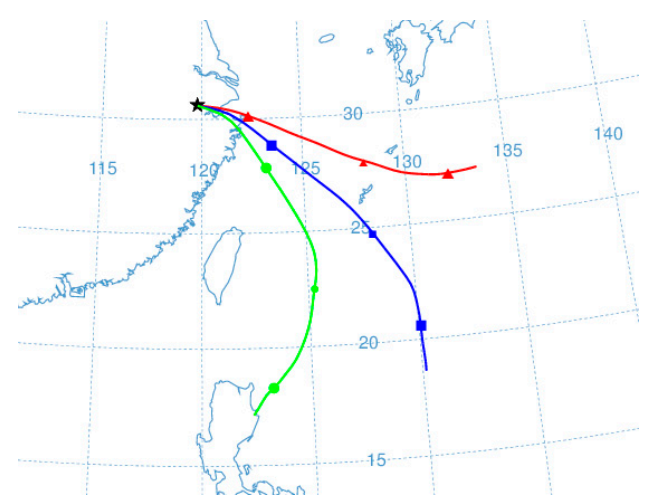

(a)

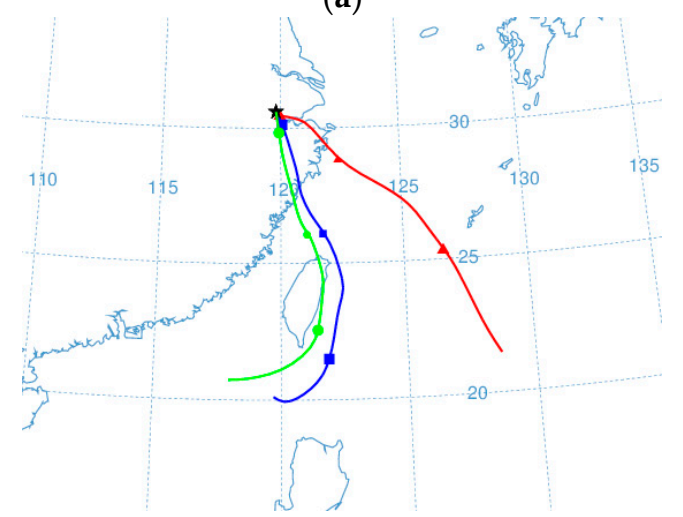

(c)

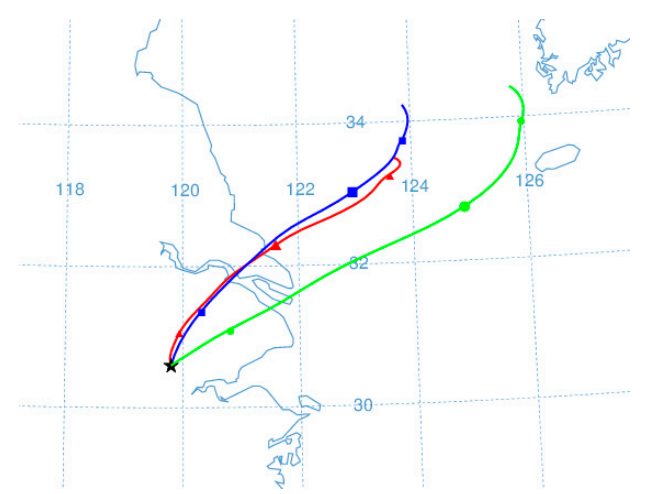

(b)

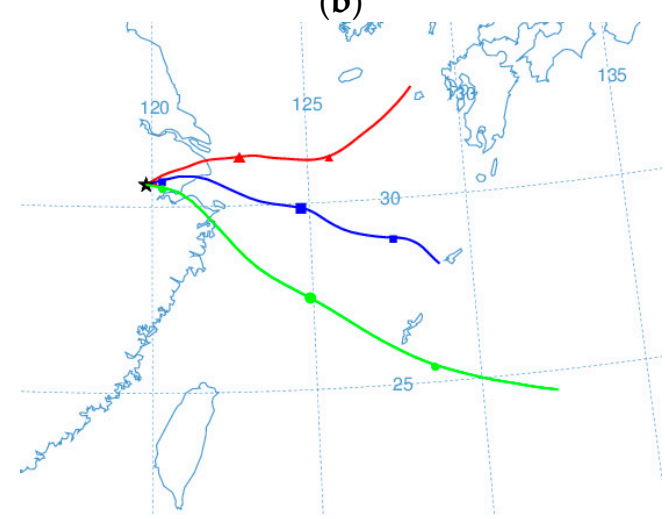

(d)

Figure 6. Moisture transport pathways to Hemuqiao basin for four typhoon events. The three colorful lines in the air trajectory figure represent three different pathways of moisture sources. Figure (a-d) represents Event 1, 2, 3 and 4, respectively. 
For two plum rain events, the air-mass trajectories that influenced Hemuqio basin are shown in Figure 7. The common ground is that the three origins all derived from the vicinity, not the local inner land but the near sea areas. From the air source trajectories, the difference between typhoon and plum rain is large, drawing the conclusion that the isotopic difference came from air source regions. In detail, the $\delta^{18} \mathrm{O}$ and $\delta^{2} \mathrm{H}$ values in plum rain varied moderately but with great difference in deuterium excess distribution. It is worth noting that lower air humidity and swifter local evaporation caused this difference in $\delta^{18} \mathrm{O}$ values and moisture source in heavy isotope enrichment during the falling of the rain. However, during sample collection, higher temperature and relative humidity resulted in stronger evaporation with respect to raindrops.

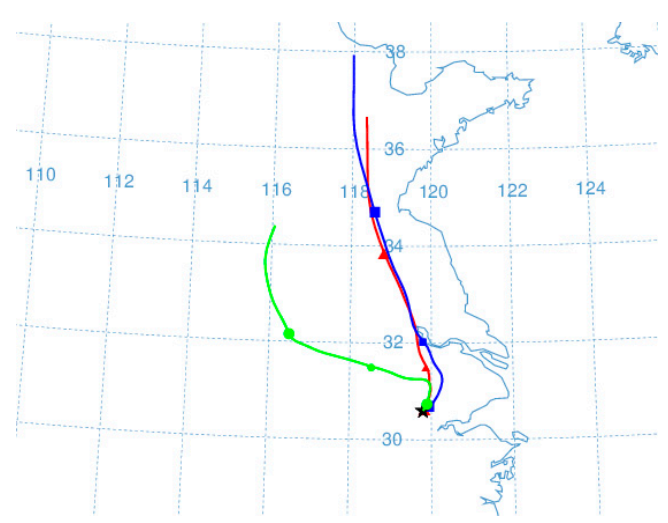

(a)

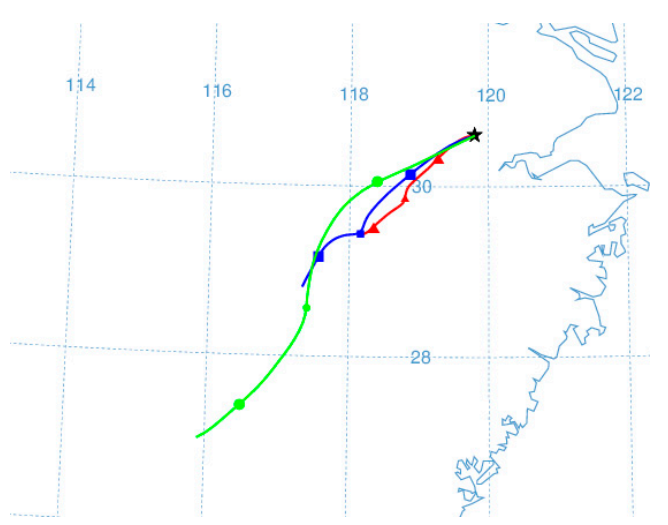

(b)

Figure 7. Moisture transport pathways to Hemuqiao basin for two plum rain events. The three colorful lines in the air trajectory figure represent three different pathways of moisture sources. Figure $(\mathbf{a}, \mathbf{b})$ represents Event 5 and 6.

As a result, different rainfall types have different moisture sources, and the difference in moisture sources could lead to variation of $\delta^{18} \mathrm{O}$ values. The moisture sources of typhoon events mostly derived from tropical sea with higher $\delta^{18} \mathrm{O}$ values; while that of plum rain events tended to come from the evaporation of near-source local air or local sea areas of China, which shows lower $\delta^{18} \mathrm{O}$ values in contrast to some researchers [52]. Because the formation mechanism of plum rain is complicated, this conflicting conclusion needs further research.

\section{Discussion}

In the paper, we measured $\delta^{2} \mathrm{H}$ and $\delta^{18} \mathrm{O}$ together with moisture source information and established the meteoric water line in Hemuqiao catchment. Based on these results we aim to obtain an improved understanding of the effect of moisture transport on stable isotopes in the lower reach of Yangtze River. Differences of isotopic characteristics between typhoon events and plum rain event were analyzed to provide an indication of the relationship in different rainfall types and isotopic composition in precipitation.

The $\delta$ value in plum rain events presented larger variations than that in typhoon events while the average $\delta$ value of plum rain events is smaller than that of typhoon events. The signals of ${ }^{18} \mathrm{O}$ revealed that precipitation geneses and moisture source were two significant factors. In general, the plum rain occurred during May to June before the typhoon with higher relative humidity and temperature because of the delay of cold and warm air masses in the atmosphere. A previous study showed that isotopic composition was mainly controlled by temperature and relative humidity [53]. The differences in rainfall types which led to condensation mechanisms and local recycled continental moisture also have an influence on the isotopic composition of rainfall events in Hemuqiao basin. During the continuous rainfall, the isotope of precipitation has a marked existence of Rayleigh distillation resulting 
in a loss of light isotopic composition and enrichment of heavy isotopic composition. It is statistically significant for the reason why the $\delta$ value in plum rain had a lower average. However, the typhoon had a prevalence dominated by tropical air masses during August to October. There was a drastic and swift transportation during the process of typhoon carried maritime air, resulting in larger variation of the $\delta$ value.

For the selected typhoon events, the d-excess was roughly lower with an average of $9.86 \%$ under the $10 \%$ line and the difference in d-excess ranged up to $3.47 \%$. Deuterium excesses showed a distinct variation in season with higher values in winter and lower values in summer [54], which accorded with this study. However, d-excess of plum rain events presented a higher value, whose reason was most likely the moisture source and precipitation genesis.

D-excess is influenced by rain re-evaporation and convective processes and a higher d-excess is mainly due to the supersaturation effect. D-excess higher than $10 \%$ usually means weaker evaporation during the congelation drops, and on the contrary, a value under $10 \%$ presents stronger evaporation like a typhoon with higher temperature. High correlation coefficients were observed between d-excess and relative humidity, representing a strong influence between d-excess and relative humidity [55]. Hence, it can be concluded that the moisture source of typhoon events had higher relative humidity and temperature, which had an implication for the source, i.e., tropical ocean at low latitudes.

Water source trajectory monitoring provides a tool to justify isotopic composition in different types of rainfall events.

\section{Conclusions}

Precipitation isotopes had a strong variation in Hemuqiao catchment. With increasing sample number, isotopic data of four rainfall events had an enrichment trend (Event 1,3,5 and 6) because of isotope condensation. There is a negative relationship between $\delta^{18} \mathrm{O}$ and rainfall amount.

Local meteoric water lines of this catchment for typhoon events and plum rain were established to reflect the difference in water sources. The two lines were different in slopes and intercepts, indicating the two rainfall types have different water sources. The slopes and intercept are lower than those in global meteoric water lines, which means precipitation isotopes are influenced by isotopic fractionation $[56,57]$.

Deuterium excess variations were analyzed for selected typhoon events and plum rain events. Higher deuterium excess and lower isotope reflected dry conditions in continental local water air and their source of water vapor [58,59]. Event 6 had lower deuterium excess with characteristic convective weather in plum rain, influenced by water evaporation in summer. Events 1, 3, 4 were three typhoon events with lower deuterium excess and higher $\delta^{2} \mathrm{H}$ and $\delta^{18} \mathrm{O}$ values different from Event 2. Deuterium excess in Event 2 was large because of the influence of re-evaporation and mixing of different sources, which need further research in water source trajectories.

The values showed a distinct difference in rainfall types, with a relatively lower value for typhoon events and higher value for plum rain events. It can be concluded that moisture source of typhoon events had higher relative humidity and temperature.

Moisture sources of four rainfall events were monitored and traced using the HYSPLIT model to reveal complex moisture sources and explain the reason for isotopic differences for different rainfall types in Hemuqiao catchment during the flood season. This study concluded that the moisture source of plum rain was derived from near-source local air due to long-time isotopic fractionation and re-evaporation with lower stable isotopic value.

Author Contributions: Conceptualization, S.Q.; Data processing, X.C.; Funding acquisition, S.Q. and P.S.; Investigation, Y.W.; S.S. and J.G.; Project administration, S.Q.; Software, Y.W.; Supervision, S.Q.; Validation, X.C.; Visualization, X.C.; Writing-original draft, S.Q.; Writing-review \& editing, P.J.; P.S.

Funding: The study is financially supported by the National Key Research and Development Program of China (2016YFC0402703), the National Natural Science Foundation of China (Nos. 41371048, 51479062, 40901015, 
51709077), the Fundamental Research Funds for the Central Universities (2017B10914), the National Postdoctoral Foundation of China (2017M611679), the Postdoctoral Foundation of Jiangsu Province (1701019A).

Acknowledgments: We thank the State Key Laboratory of Hydrology-Water Resources and Hydraulic Engineering in Hohai University for analyzing water samples. The data used in this paper will be made available upon request; please send a request to wanily@hhu.edu.cn for data.

Conflicts of Interest: The authors declare no conflict of interest. The funders had no role in the design of the study; in the collection, analyses, or interpretation of data; in the writing of the manuscript, and in the decision to publish the results.

\section{References}

1. Gat, J.R. Oxygen and hydrogen isotopes in the hydrologic cycle. Annu. Rev. Earth Planet. Sci. 1996, 24, 225-262. [CrossRef]

2. Coscarelli, R.; Caloiero, T. Analysis of daily and monthly rainfall concentration in Southern Italy (Calabria region). J. Hydrol. 2012, 416, 145-156. [CrossRef]

3. Hughes, C.E.; Crawford, J. Spatial and temporal variation in precipitation isotopes in the Sydney Basin, Australia. J. Hydrol. 2013, 489, 42-55. [CrossRef]

4. Johnson, K.R.; Ingram, B.L. Spatial and temporal variability in the stable isotope systematics of modern precipitation in China: Implications for paleoclimate reconstructions. Earth Planet. Sci. Lett. 2004, 220, 365-377. [CrossRef]

5. Jouzel, J.; Froehlich, K.; Schotterer, U. Deuterium and oxygen-18 in present-day precipitation: Data and modelling. Int. Assoc. Sci. Hydrol. Bull. 1997, 42, 747-763. [CrossRef]

6. Lachniet, M.S.; Patterson, W.P. Oxygen isotope values of precipitation and surface waters in northern Central America (Belize and Guatemala) are dominated by temperature and amount effects. Earth Planet. Sci. Lett. 2009, 284, 435-446. [CrossRef]

7. Bar-Matthews, M.; Ayalon, A.; Kaufman, A. Late Quaternary Paleoclimate in the Eastern Mediterranean Region from Stable Isotope Analysis of Speleothems at Soreq Cave, Israel. Quat. Res. 1997, 47, 155-168. [CrossRef]

8. Hren, M.T.; Bookhagen, B.; Blisniuk, P.M.; Booth, A.L.; Chamberlain, C.P. $\delta^{18} \mathrm{O}$ and $\delta \mathrm{D}$ of streamwaters across the Himalaya and Tibetan Plateau: Implications for moisture sources and paleoelevation reconstructions. Earth Planet. Sci. Lett. 2009, 288, 20-32. [CrossRef]

9. Dansgaard, W. Stable isotopes in precipitation. Tellus 1964, 16, 436-468. [CrossRef]

10. Araguásaraguás, L.; Froehlich, K.; Rozanski, K. Deuterium and oxygen-18 isotope composition of precipitation and atmospheric moisture. Hydrol. Process. 2000, 14, 1341-1355. [CrossRef]

11. Chhetri, T.B.; Yao, T.; Tian, L.; Zhang, X. Amount and temperature effects responsible for precipitation isotope variation in the southern slope of Himalayas. Sci. Cold Arid Reg. 2013, 5, 165-176.

12. Liu, J.; Song, X.; Fu, G.; Liu, X.; Zhang, Y.; Hand, D. Precipitation isotope characteristics and climatic controls at a continental and an island site in Northeast Asia. Clim. Res. 2011, 49, 29-44. [CrossRef]

13. Eastoe, C.J.; Dettman, D.L. Isotope amount effects in hydrologic and climate reconstructions of monsoon climates: Implications of some long-term data sets for precipitation. Chem. Geol. 2016, 430, 78-89. [CrossRef]

14. Yu, R.; Yu, Y.; Zhou, T.; Li, J. Relation between rainfall duration and diurnal variation in the warm season precipitation over central eastern China. Geophys. Rese. Lett. 2007, 34, 173-180. [CrossRef]

15. Yao, T.; Masson, V.; Jouzel, J.; Stievenard, M.; Weizhen, S.; Keqin, J. Relationships between $\delta^{18} \mathrm{O}$ in precipitation and surface air temperature in the Urumqi River Basin, East Tianshan Mountains, China. Geophys. Res. Lett. 1999, 26, 3473-3476.

16. Siegenthaler, U.; Oeschger, H. Correlation of ${ }^{18} \mathrm{O}$ in precipitation with temperature and altitude. Nature 1980, 285, 314-317. [CrossRef]

17. Hughes, C.E.; Crawford, J. A new precipitation weighted method for determining the meteoric water line for hydrological applications demonstrated using Australian and global GNIP data. J. Hydrol. 2012, 464-465, 344-351. [CrossRef]

18. Hughes, C.E.; Crawford, J. A rainfall amount weighted meteoric water line for use in hydrological applications. In Proceedings of the EGU General Assembly Conference, Vienna, Austria, 19-24 April 2009. 
19. Voelker, S.L.; Brooks, J.R.; Meinzer, F.C.; Roden, J.; Pazdur, A.; Pawelczyk, S.; Hartsough, P.; Snyder, K.; Plavcová, L.; Santrůcek, J. Reconstructing relative humidity from plant delta ${ }^{18} \mathrm{O}$ and delta $\mathrm{D}$ as deuterium deviations from the global meteoric water line. Ecol. Appl. 2014, 24, 960-975. [CrossRef] [PubMed]

20. Lacelle, D. On the $\delta^{18} \mathrm{O}, \delta \mathrm{D}$ and D-excess relations in meteoric precipitation and during equilibrium freezing: theoretical approach and field examples. Permafr. Periglac. Process. 2011, 22, 13-25. [CrossRef]

21. Jouzel, J.; Merlivat, L.; Lorius, C. Deuterium excess in an East Antarctic ice core suggests higher relative humidity at the oceanic surface during the last glacial maximum. Nature 1982, 299, 688-691. [CrossRef]

22. Stenni, B.; Genoni, L.; Flora, O.; Guglielmin, M. An oxygen isotope record from the Foscagno rock-glacier ice core, Upper Valtellina, Italian Central Alps. Holocene 2007, 17, 1033-1039. [CrossRef]

23. Liu, J.; Fu, G.; Song, X.; Charles, S.P.; Zhang, Y.; Han, D.; Wang, S. Stable isotopic composition in Australian precipitation. J. Geophys. Res. Atmos. 2010, 115, 6696-6705. [CrossRef]

24. Lai, C.T.; Ehleringer, J.R. Deuterium excess reveals diurnal sources of water vapor in forest air. Oecologia 2011, 165, 213-223. [CrossRef] [PubMed]

25. Xie, L.; Wei, G.; Deng, W.; Zhao, X. Daily $\delta^{18} \mathrm{O}$ and $\delta \mathrm{D}$ of precipitations from 2007 to 2009 in Guangzhou, South China: Implications for changes of moisture sources. J. Hydrol. 2011, 400, 477-489. [CrossRef]

26. Bowen, G.J.; Kennedy, C.D.; Henne, P.D.; Zhang, T. Footprint of recycled water subsidies downwind of Lake Michigan. Ecosphere 2012, 3, 1-16. [CrossRef]

27. Liu, J.; Song, X.; Yuan, G.; Sun, X.; Liu, X.; Wang, Z.; Wang, S. Stable isotopes of summer monsoonal precipitation in southern China and the moisture sources evidence from $\delta^{18} \mathrm{O}$ signature. J. Geogr. Sci. 2008, 18, 155-165. [CrossRef]

28. Aizen, V.; Aizen, E.; Melack, J.; Martma, T. Isotopic measurements of precipitation on central Asian glaciers (southeastern Tibet, northern Himalayas, central Tien Shan). J. Geophys. Res. Atmos. 1996, 101, 9185-9196. [CrossRef]

29. Tian, L.; Yao, T.; MacClune, K.; White, J.W.C.; Schilla, A.; Vaughn, B.; Vachon, R.; Ichiyanagi, K. Stable isotopic variations in west China: A consideration of moisture sources. J. Geophys. Res. Atmos. 2007, 112. [CrossRef]

30. Brimelow, J.C.; Reuter, G.W. Transport of Atmospheric Moisture during Three Extreme Rainfall Events over the Mackenzie River Basin. J. Hydrometeorol. 2005, 6, 423-440. [CrossRef]

31. Perry, L.B.; Konrad, C.E.; Schmidlin, T.W. Antecedent Upstream Air Trajectories Associated with Northwest Flow Snowfall in the Southern Appalachians. Weather Forecast. 2007, 22, 334-352. [CrossRef]

32. Kennedy, V.C.; Zellweger, G.W.; Avanzino, R.J. Variation of rain chemistry during storms at two sites in northern California. Water Resour. Res. 1979, 15, 687-702. [CrossRef]

33. Brenninkmeijer, C.A.M.; Geel, B.V.; Mook, W.G. Variations in the D/H and ${ }^{18} \mathrm{O} /{ }^{16} \mathrm{O}$ ratios in cellulose extracted from a peat bog core. Earth Planet. Sci. Lett. 1982, 61, 283-290. [CrossRef]

34. Gonfiantini, R. Standards for stable isotope measurements in natural compounds. Nature 1978, 271, 534-536. [CrossRef]

35. Draxler, R.R.; Hess, G.D. An overview of the hysplit-4 modeling system for trajectories. Aust. Meteorol. Mag. 1998, 47, 295-308.

36. Moroz, B.E.; Beck, H.A.; Simon, S.L. Predictions of dispersion and deposition of fallout from nuclear testing using the NOAA-HYSPLIT meteorological model. Health Phys. 2010, 99, 252-269. [CrossRef] [PubMed]

37. Stein, A.F.; Draxler, R.R.; Rolph, G.D.; Stunder, B.J.B.; Cohen, M.D.; Ngan, F. NOAA's HYSPLIT Atmospheric Transport and Dispersion Modeling System. Bull. Am. Meteorol. Soc. 2016, 96, 2059-2077. [CrossRef]

38. Chou, C.; Neelin, J.D. Mechanisms of Global Warming Impacts on Regional Tropical Precipitation. J. Clim. 2004, 17, 2688-2701. [CrossRef]

39. Chou, C.; David Neelin, J.; Chen, C.-A.; Tu, J.-Y. Evaluating the "rich-get-richer" mechanism in tropical precipitation change under global warming. J. Clim. 2009, 22, 1982-2005. [CrossRef]

40. Craig, H. Isotopic Variations in Meteoric Waters. Science 1961, 133, 1702-1703. [CrossRef] [PubMed]

41. Gourcy, L.L.; Groening, M.; Aggarwal, P.K. Stable oxygen and hydrogen isotopes in precipitation. In Isotopes in the Water Cycle: Past, Present and Future of Developing Science; Aggarwal, P.K., Gat, J.R., Froehlich, K.F.O., Eds.; Springer: Dordrecht, The Netherlands, 2005; pp. 39-51.

42. Weyhenmeyer, C.E.; Burns, S.J.; Waber, H.N.; Macumber, P.G.; Matter, A. Isotope study of moisture sources, recharge areas, and groundwater flow paths within the eastern Batinah coastal plain, Sultanate of Oman. Water Resour. Res. 2002, 38. [CrossRef] 
43. Crawford, J.; Hughes, C.E.; Lykoudis, S. Alternative least squares methods for determining the meteoric water line, demonstrated using GNIP data. J. Hydrol. 2014, 519, 2331-2340. [CrossRef]

44. Ray, J.S.; Ramesh, R. Rayleigh fractionation of stable isotopes from a multicomponent source. Geochim. Cosmochim. Acta 2000, 64, 299-306. [CrossRef]

45. Gou, J.; Qu, S.; Shi, P.; Li, D.; Chen, X.; Wang, Y.; Si, W. Application of Stable Isotope Tracer to Study Runoff Generation during Different Types of Rainfall Events. Water 2018, 10, 538. [CrossRef]

46. Sayres, D.S.; Pfister, L.; Hanisco, T.F.; Moyer, E.J.; Smith, J.B.; St. Clair, J.M.; OBrien, A.S.; Witinski, M.F.; $\mathrm{Leg}, \mathrm{M}$. Influence of convection on the water isotopic composition of the tropical tropopause layer and tropical stratosphere. J. Geophys. Res. Atmos. 2010, 115, D00J20. [CrossRef]

47. Vimeux, F.; Masson, V.; Jouzel, J.; Petit, J.-R.; Steig, E.J.; Stiévenard, M.; Vaikmäe, R.; White, J.W.C. Holocene hydrological cycle changes in the Southern Hemisphere documented in East Antarctic deuterium excess records. Clim. Dyn. 2001, 17, 503-513. [CrossRef]

48. Froehlich, K.; Kralik, M.; Papesch, W.; Rank, D.; Scheifinger, H.; Stichler, W. Deuterium excess in precipitation of Alpine regions-Moisture recycling. Isotopes Environ. Health Stud. 2008, 44, 61-70. [CrossRef] [PubMed]

49. Kitoh, A.; Uchiyama, T. Changes in Onset and Withdrawal of the East Asian Summer Rainy Season by Multi-Model Global Warming Experiments. J. Meteorol. Soc. Jpn. 2006, 84, 247-258. [CrossRef]

50. Ding, Y.; Wang, Z.; Sun, Y. Inter-decadal variation of the summer precipitation in East China and its association with decreasing Asian summer monsoon. Part I: Observed evidences. Int. J. Climatol. 2008, 28, 1139-1161. [CrossRef]

51. Zhu, G.F.; Li, J.F.; Shi, P.J.; He, Y.Q.; Cai, A.; Tong, H.L.; Liu, Y.F.; Yang, L. Relationship between sub-cloud secondary evaporation and stable isotope in precipitation in different regions of China. Environ. Earth Sci. 2016, 75, 876. [CrossRef]

52. Wu, H.; Zhang, X.; Li, X.; Li, G.; Huang, Y. Seasonal variations of deuterium and oxygen-18 isotopes and their response to moisture source for precipitation events in the subtropical monsoon region. Hydrol. Process. 2015, 29, 90-102. [CrossRef]

53. Wu, J.K.; Ding, Y.; Ye, B.; Yang, Q.; Zhang, X.; Wang, J. Spatio-temporal variation of stable isotopes in precipitation in the Heihe River Basin, Northwestern China. Environ. Earth Sci. 2010, 61, 1123-1134. [CrossRef]

54. Lee, K. Climatic controls on the stable isotopic composition of precipitation in Northeast Asia. Clim. Res. 2003, 23, 137-148. [CrossRef]

55. Landais, A.; Risi, C.; Bony, S.; Vimeux, F.; Descroix, L.; Falourd, S.; Bouygues, A. Combined measurements of $17 \mathrm{O}$ excess and d-excess in African monsoon precipitation: Implications for evaluating convective parameterizations. Earth Planet. Sci. Lett. 2010, 298, 104-112. [CrossRef]

56. Melchiorre, E.B.; Criss, R.E.; Rose, T.P. Oxygen and carbon isotope study of natural and synthetic azurite. Econ. Geol. 2000, 95, 621-628. [CrossRef]

57. Criss, R.E.; Farquhar, J. Abundance, notation, and fractionation of light stable isotopes. Rev. Mineral. Geochem. 2008, 68, 15-30. [CrossRef]

58. Ingraham, N.L.; Criss, R.E. Effects of surface area and volume on the rate of isotopic exchange between water and water vapor. J. Geophys. Res. Atmos. 1993, 98, 20547-20553. [CrossRef]

59. Criss, R.E.; Fernandes, S.A.; Winston, W.E. Isotopic, geochemical and biological tracing of the source of an impacted karst spring, Weldon spring, Missouri. Environ. Forensics 2001, 2, 99-103. [CrossRef]

(C) 2018 by the authors. Licensee MDPI, Basel, Switzerland. This article is an open access article distributed under the terms and conditions of the Creative Commons Attribution (CC BY) license (http://creativecommons.org/licenses/by/4.0/). 